UDC 343.431

LBC 67.408.112

\title{
THE MIGRANT'S PERSONALITY AS ONE OF THE ELEMENTS OF CRIMINALISTIC NATURE OF ILLEGAL MIGRATION
}

\author{
Svyatoslav Yu. Biryukov \\ Volgograd Academy of the Ministry of the Interior of Russia, Volgograd, Russian Federation \\ Dmitriy G. Skorikov \\ Volgograd Academy of the Ministry of the Interior of Russia, Volgograd, Russian Federation
}

\begin{abstract}
Introduction. The existence of human civilization is accompanied by migration of individual peoples and nations. Migration processes have important labor force redistribution functions to overcome the differences in lifestyle, convergence and interpenetration of cultures. However, since the second half of the twentieth century under the influence of the collapse and the formation of new states, such disasters as the world wars, the expansion of international relations and the changing nature of relationships between nations, the phenomenon of migration has qualitatively changed, creating a new image of human communities and becoming a powerful conflict factor. Crime situation in our country shows that illegal migration has become an integral part of a criminal business structure and, of course, has an impact on the entire system of economic relations, criminalizing the national economy, increasing its shadow sector. It not only transformed into a well-organized commercial activities at the international level, but also more recently coexists with other forms of international organized crime (trafficking in drugs, weapons, "human beings" and so forth.). In this connection, the authors set the purpose to reveal the contents of one of the most important elements of criminological characteristics of the organization of illegal migration - identity of illegal migrants in the territory of Russia. Methods. The methodological framework of this study constitutes a set of methods of scientific knowledge, among which the main place is occupied by methods of information processing and logical analysis, synthesis, induction, deduction and generalization, systematization. Results presented in the author's content element forensic characteristics of the organization of illegal migration the individual migrants relying on the judicial and investigative practice, analytical reviews of the Russian Interior Ministry in the field of migration policy allows the use of forensic characterization of a functional-pragmatic model of crime, created on the basis of science and practice orientation to the subject of the investigation in the features of the personality of illegal migrants and other forensically relevant information. Conclusions. The study provided detailed description of the personality of illegal migrants to inform the students with the profile in "Jurisprudence", teachers of law schools, as well as persons carrying out an investigation organization of illegal migration in order to better understand the migration processes, as well as the quality of the crimes investigation related to the organization of illegal migration.
\end{abstract}

Key words: migration, foreign citizen, stateless person, migrant, illegal resident, employer, communities, residential areas.

\section{ЛИЧНОСТЬ МИГРАНТА КАК ОДИН ИЗ ЭЛЕМЕНТОВ КРИМИНАЛИСТИЧЕСКОЙ ХАРАКТЕРИСТИКИ ОРГАНИЗАЦИИ НЕЗАКОННОЙ МИГРАЦИИ}

\author{
Святослав Юрьевич Бирюков \\ Волгоградская академия МВД России, г. Волгоград, Российская Федерация
}




\section{Дмитрий Геннадьевич Скориков}

Волгоградская академия МВД России, г. Волгоград, Российская Федерация

Введение: существование человеческой цивилизации сопровождается миграциями отдельных народностей и целых наций. Миграционные процессы выполняют важные функции перераспределения трудовых ресурсов, преодоления различий в образе жизни, сближения и взаимопроникновения культур.

Однако начиная со второй половины ХХ в. под влиянием распада и формирования новых государств, таких катаклизмов, как мировые войны, расширение международных связей и изменение характера взаимоотношений между народами, миграция качественно изменилась, сформировав новый облик человеческих сообществ и став мощным конфликтогенным фактором.

Криминогенная обстановка в нашей стране свидетельствует, что незаконная миграция стала неотъемлемой частью структуры преступного бизнеса и, безусловно, до сих пор оказывает влияние на состояние всей системы экономических отношений, криминализируя национальную экономику, увеличивая ее теневой сектор. Она не только превращается в хорошо организованную коммерческую деятельность на международном уровне, но и с недавнего времени соседствует с другими видами международной организованной преступности (торговля наркотиками, оружием, «живым товаром» и пр.).

В связи с этим авторами поставлена цель раскрыть содержание одного из важнейших элементов криминалистической характеристики организации незаконной миграции - личности незаконного мигранта, находящегося на территории России. Методы: методологическую основу данного исследования составляет совокупность методов научного познания, среди которых основное место занимают методы обработки информации и логического анализа, синтеза, индукции, дедукции и обобщения. Результаты: представленное в работе авторское содержание элемента криминалистической характеристики организации незаконной миграции - личности мигранта, опирающееся на судебно-следственную практику, аналитические обзоры МВД России в сфере миграционной политики, дает возможность использовать криминалистическую характеристику как функционально-прагматическую модель преступления, создаваемую на основе науки и практики в целях ориентации субъекта расследования в особенностях личности незаконного мигранта и другой криминалистически значимой информации. Выводы: по итогам исследования дана всесторонняя характеристика личности незаконного мигранта для информирования обучающихся по направлению подготовки «Юриспруденция», педагогических работников юридических вузов, а также практических работников в целях более полного понимания миграционных процессов, а также качественного расследования преступлений, связанных с организацией незаконной миграции.

Ключевые слова: миграция, иностранный гражданин, апатрид, мигрант, нелегал, работодатель, землячества, общины.

\section{Введение}

Незаконные мигранты, находящиеся в Российской Федерации, - это выходцы из почти 70 стран, как правило, Африки и Азии. Говоря о странах так называемого ближнего зарубежья, откуда в нашу страну идет основной поток мигрантов, здесь в первую очередь можно назвать Таджикистан, Украину, Молдову, Азербайджан и Грузию.

В настоящий момент, по разным оценкам, число лиц, незаконно находящихся на территории России, составляет от 2,7 до 7 млн человек [4].

\section{Виды незаконных мигрантов}

С учетом целей, стоящих перед правоохранительными органами, представляется целесообразным использовать классификацию незаконных мигрантов в зависимости от критерия отнесения лица к категории незаконного мигранта:

1. Мигрант, находившийся в России для получения образования или трудовой деятельности на основании соответствующего международно-правового договора, но после окончания установленных сроков пребывания не покинувший территорию страны.

В СССР, а затем и в Российской Федерации в течение длительного времени обучались и осуществляли трудовую деятельность иностранные граждане из стран СНГ, Азии и Африки. Полученное образование, знакомство с культурой и менталитетом российского общества способствовали возникновению желания среди указанной категории лиц реализовать свои возможности именно в России. 
2. Мигрант, находившийся в России на законных основаниях, но с иной, нежели указанной в документах, целью.

Данный способ миграции отличается простотой и эффективностью, что и предопределяет его распространенность; он используется мигрантами для достижения своих целей пребывания в конкретной стране.

3. Мигрант, находившийся в России по поддельным документам.

Данный способ миграции характерен для лиц - членов транснациональных преступных формирований.

4. Мигрант, находившийся в России без соответствующих документов, посредством нелегального пересечения государственной границы.

Данный способ характерен для потенциальных правонарушителей. Исследования, проведенные в последние годы в России, свидетельствуют, что большинство мигрантов выходцы из крупных (около 60 \%) и небольших городов (около $25 \%$ ), а также жители сельской местности (не более $15 \%$ ) [2, с. 34].

Как известно, основными элементами нелегальной миграции являются: нелегальный въезд, нелегальное пребывание и нелегальная занятость. Последняя в нашей стране получила наибольшее распространение. Разрешение на занятие трудовой деятельностью имеют около 30 \% мигрантов, около $50 \%$ зарегистрированы по месту проживания [1, с. 57].

\section{Характеристика незаконных мигрантов}

Изучение процессов трудовой занятости мигрантов в различных субъектах Федерации дает основание говорить о схожести структурирования рынка труда нашей страны и других принимающих стран. В России происходит процесс дифференциации труда на основе этнической и тендерной сегрегации работников из числа мигрантов, который осуществляется как по отраслевому, так и по территориальному признаку. В этой связи необходимо иметь в виду, что работодатели привыкают нанимать мигрантов и работать вне правового поля, что обеспечивает им известные выгоды. Все это способствует созданию и функционированию определенного порядка, который направлен исключительно на найм мигрантов.

Исследования Центра демографии и экологии человека Института народно-хозяйственного прогнозирования РАН показывают, что $50 \%$ рабочих мест, на которых трудятся мигранты, являются зарезервированными за ними на долгие годы, а оставшиеся 50 \% - это сектора, где существует конкуренция с российскими работниками [5]. Примерно 30 \% работающих мигрантов осуществляют свою трудовую деятельность на постоянной основе. Работа выбирается та, которая попадется (40\%), а не та, на которой больше платят (29\%) или где лучше условия труда (16\%). В основном мигранты заняты на местах, требующих либо средней квалификации (52 \%), либо неквалифицированных рабочих (27 \%). Квалифицированным профессиональным трудом занято примерно 20 \% мигрантов [2, с. 34]. Безработных мигрантов в России около $10 \%$. Оставшаяся часть, как правило, работает либо совмещает работу с учебой. Около $30 \%$ занято в сфере торговли, около $20 \%$ в строительстве и около $25 \%$ - в сфере услуг [2, с. 35].

Что касается китайской миграции, то оценить ее численность в нашей стране пока нереально. По приблизительным подсчетам правоохранительных органов, только в Сибири и на Дальнем Востоке могут находиться около 2 млн граждан КНР [6].

Основная проблема, связанная с китайской миграцией, заключается в настоящее время в экономическом ущербе, наносимом нашей стране, что стало возможно из-за быстрого формирования в России китайских общин. Так, например, в китайской общине в Москве существуют многочисленные фирмы, основной вид деятельности которых - концентрация средств китайских предпринимателей в России и организация с их помощью поставок к себе на родину природного сырья и промышленных изделий; использование каргофирм для ввоза в Россию крупных партий товаров и т. д. [2, с. 42]

По экспертным оценкам, корейская иммиграция в настоящее время носит ярко выраженный экономический характер: открытие бизнеса в нашей стране является целью около $60 \%$ опрошенных мигрантов [2, с. 44]. 
Своеобразным центром организации и координирования корейской миграции являются религиозные миссионерские организации, зарегистрированные в крупнейших городах нашей страны. Данные организации выполняют функции рекрутирования для общины новых членов, трудоустройства и финансовой взаимопомощи мигрантов. Под их контролем находится большая часть мелкого и даже среднего бизнеса. Миссионерские организации осуществляют деятельность, направленную на вовлечение в свою сферу миграционных потоков корейцев из других, менее благополучных по отношению к России стран, и в первую очередь из республик Средней Азии [2, c. 49].

По различным оценкам, численность вьетнамских мигрантов в нашей стране оценивается от 90 до 130 тыс. человек. Вьетнамские незаконные мигранты в различной степени опираются на помощь официально зарегистрированных в России организаций вьетнамской общины. В сфере организации бизнеса ею пользуются 17-29 \% мигрантов, в осуществлении инвестиций $-7-12 \%$, в улаживании спорных проблем - 14-21\%, в проведении маркетинга - 4-20\%, в получении консультаций - 21-30 \%, в защите прав человека $-12-27 \%$.

Вместе с тем отношение государственных вьетнамских структур к своим соотечественникам в России сильно отличается от китайских. Вьетнам очень осторожно относится к защите прав соотечественников, особенно в конфликтных ситуациях [2, с. 50]. Опросы вьетнамских мигрантов показывают, что около $15 \%$ из них хотят получить гражданство России, около $30 \%$ - иметь постоянный вид на жительство, около $10 \%$ - временное разрешение на коммерческую деятельность, около 50 \% намерены вернуться на родину [5].

Основной вид миграции в Россию - экономическая миграция. Средний доход трудового мигранта в России примерно в 3-4 раза выше, чем на родине. Около $30 \%$ из них имели в своей стране постоянную работу, еще $16 \%$ - временную, а около $20 \%$ обучались в учебных заведениях. Примерно $30 \%$ трудовых мигрантов, находящихся в России, пересылают часть заработанных денег на родину.
Причем, как правило, это делается через проводников или друзей [2, с. 38].

Неофициальные и неформальные отношения и связи превалируют в мигрантской среде, что является ахиллесовой пятой государственных структур, обеспечивающих миграционные процессы. Так, для 50 \% мигрантов друзья и знакомые - основной источник информации о возможности приезда. Они же, как правило, и оказывают помощь в переезде и поиске работы.

\section{Выводы}

Наибольшими проблемами незаконных мигрантов являются: сложности в легализации статуса, отрыв от семьи, отсутствие квалифицированной медицинской помощи, плохое жилье. Указанные обстоятельства усугубляются сложностью интеграции, негативным отношением властей и нетолерантностью местного населения.

Основными намерениями мигрантов являются: получение российского гражданства и последующее постоянное проживание в стране либо быстрый заработок и возвращение на родину. Зачастую в планах мигрантов пребывание в России около года, однако наиболее распространенный срок их пребывания - около шести месяцев.

Большинство незаконных мигрантов (около $55 \%$ ) считают отношение к себе местных жителей доброжелательным или нейтральным, около $30 \%$ - не очень доброжелательным и около $7 \%$ оценивают его как враждебное.

Основная часть мигрантов въехала на территорию нашей страны по гостевым (39\%), туристическим (31\%) и учебным (11\%) визам. Небольшая часть мигрантов оказалась на территории РФ, используя безвизовый режим въезда со странами СНГ, либо незаконно пересекла государственную границу (последних не более $2 \%$ ). Мигранты из дальнего зарубежья попали на территорию нашей страны с помощью переправщиков, при непосредственном содействии туристических агентств, знакомых и родственников. Стоимость услуг переправщиков составляет от 1 до 3,5 тыс. долларов США. Деньги на дорогу им собрали родственники в надежде на то, что, 
перебравшись на Запад, они смогут помогать своим близким. Путь в Россию у мигрантов занимает от 1,5 до 3 месяцев [8].

\section{СПИСОК ЛИТЕРАТУРЫ}

1. Бирюков, С. Ю. Особенности расследования организации незаконной миграции : дис. ... канд. юрид. наук / Бирюков Святослав Юрьевич. - Волгоград, 2008. - $226 \mathrm{c.}$

2. Бирюков, С. Ю. Особенности расследования организации незаконной миграции / С. Ю. Бирюков. - Волгоград : ВА МВД России, 2010. - 144 с.

3. Жуков, Л. А. Преступность в России / Л. А. Жуков. - Челябинск, 2003.

4. Москвина, М. В. Влияние миграции на социально-экономические проблемы / М. В. Москвина // Миграция и внутренняя безопасность. Аспекты взаимодействия. - М., 2003.

5. Незаконная миграция в России (по материалам конф. «Незаконные мигранты в России: ситуация, тенденции, политика», Москва, 24 апр. 2003 г.). - Электрон. текстовые дан. - Режим доступа: http://demoscope.ru/weekly/2003/0111/analit05. php. - Загл. с экрана.

6. Нырова, Н. Н. Китайские компании приграничной торговли и их место в международной преступной деятельности / Н. Н. Нырова // «Черные дыры» в российском законодательстве. - 2003. № 3. - С. 263-280.

7. Официальный сайт ООН. - Электрон. дан. Режим доступа: http://www.un.org. - Загл. с экрана.

8. Щеблыкина, И. В. Незаконная миграция и ее проявления в пограничном пространстве Российской Федерации / И. В. Щеблыкина // Закономерности преступности, стратегия борьбы и закон. - М. : Криминологическая ассоциация, 2001. C. 170-180.

\section{REFERENCES}

1. Biryukov S.Yu. Osobennosti rassledovaniya organizatsii nezakonnoy migratsii: dis. ... kand. yurid. nauk [Features of investigation of the organization of illegal migration. Cand. jurid. sci. diss.]. Volgograd, 2008. 226 p.

2. Biryukov S.Yu. Osobennosti rassledovaniya organizatsii nezakonnoy migratsii [Features of investigation of the organization of illegal migration]. Volgograd, VA MVD Rossii Publ., 2010. 144 p.

3. Zhukov L.A. Prestupnost $v$ Rossii [Crime in Russia]. Chelyabinsk, 2003.

4. Moskvina M.V. Vliyanie migratsii na sotsialnoekonomicheskie problemy [The impact of migration on the socio-economic problems]. Migratsiya $i$ vnutrennyaya bezopasnost. Aspekty vzaimodeystviya [Migration and internal security. Aspects of interaction]. Moscow, 2003.

5. Nezakonnaya migratsiya $v$ Rossii: materialy konf. "Nezakonnye migranty v Rossii: situatsiya, tendentsii, politika», Moskva, 24 apr. 2003 g. [Illegal migration in Russia: materials of conference "Illegal migrants in Russia: situation, trends and policy", Moscow, April 24, 2003]. Available at: http:// demoscope.ru/weekly/2003/0111/analit05. php.

6. Nyrova N.N. Kitayskie kompanii prigranichnoy torgovli i ikh mesto $\mathrm{v}$ mezhdunarodnoy prestupnoy deyatelnosti [Chinese companies and their cross-border trade in the international criminal activities]. «Chernye dyry» v rossiyskom zakonodatelstve, 2005, no. 3, pp. 263-280.

7. Ofitsialnyy sayt OON [Official Site of the UN]. Available at: http://www.un.org.

8. Shcheblykina I.V. Nezakonnaya migratsiya i ee proyavleniya v pogranichnom prostranstve Rossiyskoy Federatsii [Illegal migration and its manifestations in the border area of the Russian Federation]. Zakonomernosti prestupnosti, strategiya borby i zakon [Patterns of crime, prevention strategy and law]. Moscow, Kriminologicheskaya assotsiatsiya Publ., 2006, pp. 170-180.

\section{Information About the Authors}

Svyatoslav Yu. Biryukov, Candidate of Juridical Sciences, Associate Professor, Head of Department of Preliminary Investigation, Educational and Research Complex on Preliminary Investigation in the Bodies of Internal Affairs, Volgograd Academy of the Ministry of the Interior of Russia, Istoricheskaya St., 130, 400089 Volgograd, Russian Federation, Bir.slav@yandex.ru.

Dmitriy G. Skorikov, Candidate of Juridical Sciences, Associate Professor, Department of Preliminary Investigation, Educational and Research Complex on Preliminary Investigation in the Bodies of Internal Affairs, Volgograd Academy of the Ministry of the Interior of Russia, Istoricheskaya St., 130, 400089 Volgograd, Russian Federation, Bir.slav@yandex.ru. 


\section{ПРОЦЕССУАЛЬНОЕ ПРАВО: ВОПРОСЫ ТЕОРИИ И ПРАВОПРИМЕНЕНИЯ}

\section{Информация об авторах}

Святослав Юрьевич Бирюков, кандидат юридических наук, доцент, начальник кафедры предварительного расследования учебно-научного комплекса по предварительному следствию в органах внутренних дел, Волгоградская академия МВД России, ул. Историческая, 130, 400089 г. Волгоград, Российская Федерация, Bir.slav@yandex.ru.

Дмитрий Геннадьевич Скориков, кандидат юридических наук, доцент кафедры предварительного расследования учебно-научного комплекса по предварительному следствию в органах внутренних дел, Волгоградская академия МВД России, ул. Историческая, 130, 400089 г. Волгоград, Российская Федерация, Bir.slav@yandex.ru. 